\title{
PUBLIC INTERESTS PROVISION IN THE ACTIVITIES OF CONTROL AND ACCOUNTS BODIES OF THE SUBJECTS OF THE RUSSIAN FEDERATION
}

\author{
ELENA KIREEVA ${ }^{1}$
}

\begin{abstract}
This contribution deals with the analysis of the activity of control and accounts bodies (CAB) in the subjects of the Russian Federation. Based on the results of monitoring the data published at the official websites of the $\mathrm{CAB}$ and using the method of comparative legal analysis, the Author makes an attempt at assessing the activity of $\mathrm{CAB}$ in terms of openness, studies the issues in the legal regulation of their activity, reviews available feedback mechanisms and the forms of protection and representation of interests of civil society in the course of financial control implementation. We conclude that currently the created information resources ensure publicity in the work of $\mathrm{CAB}$ of the subjects of the Russian Federation by providing information on the composition, structure, performance (publication of reports, statistical and analytical materials), contact information including schedules for citizens however there is a number of problems and shortcomings in terms of ensuring the interaction of citizens and control and accounts bodies, among which one can point out that some websites do not provide the possibility of submitting on-line appeals, as well as obtaining information on the results of the examination of the latter.
\end{abstract}

\section{Keywords}

Public interests; control and accounts bodies; subjects of the Russian Federation

\section{JEL Classification: K34, K40, M40}

1 Doctor of Legal Sciences, Dean of the Faculty of Personnel Management and Civil Service of the Institute of Public Administration and Civil Service of the Russian Presidential Academy of National Economy and Public Administration, Russian Federation. She is a member of the Advisory Board of the Higher Attestation Commission under the Ministry of Education and Science of the Russian Federation. She is the author of 3 books and more than 45 reviewed articles in prestigious journals. Contact email: elena_kireeva02@mail.ru. 


\section{Introduction}

In this article the Author presents the results of monitoring the official websites of control and accounts bodies of the subjects of the Russian Federation concerning control exercising by civil society institutions over the activities of the $\mathrm{CAB}$ (Control and Accounts Bodies) of the subjects of the Russian Federation, and also the feedback mechanisms use.

On the basis of the methods of systematic, comparative legal analysis and monitoring, the study of normative regulation of activities of control and accounts bodies of constituent entities of the Russian Federation is made; the conclusions about the openness of CAB activities of the RF subjects and forms of protection and representation of interests of civil society in the implementation of financial control are formulated.

\section{Analysis of Constitutional Norms}

The principle of the primacy of the good of the people formulated by Cicero and proclaimed in Roman law - Salus populi suprema lex esto - has undergone a significant transformation and has received various incarnations both in the legislative systems and the real power mechanisms of modern states. And if at the initial stages of statehood it was implemented in the activities of parliaments designed to represent the will and interests of the people, later with the development of democratic institutions, it became a universal principle of the activity of public authorities and found its normative consolidation in the constitutions of modern states.

Thus, the Constitution of the Russian Federation (adopted by popular vote on 12 December 1993) proclaims: "A person, his rights, and freedoms are the highest value. Recognition, observance, and protection of human and citizen's rights and freedoms is the duty of the state" (Constitution of the Russian Federation, Art. 2). In the Constitution of Lithuania, it's stipulated that "institutions of power serve people" (Constitution of Lithuania, Art. 5). The Constitution of the Republic of Poland of 2 April 1997 declares that this state "shall be the common good of all its citizens" (Constitution of the Republic of Poland, Art. 1) and that it is "a democratic state ruled by law and implementing the principles of social justice" (Constitution of the Republic of Poland, Art. 2).

Unlike Eastern European states, Russia has a federal structure and two levels of public authority - the federal and the constituent entities of the Russian Federation, for which general principles for the organization of a system of public authorities 
Public Interests Provision in the Activities of Control and Accounts Bodies...

and local self-government have been established in clause "n" Art. 72 of the Constitution of the Russian Federation.

Being applied to the control and accounts bodies of the subjects of the Russian Federation, which are the object of close scrutiny by representatives of the science of financial and budgetary law, the principles for their organization and activities are set forth in Act on the general principles of organization and operation of control and accounting bodies of the subjects of the Russian Federation and municipal entities (Act 6-FZ/2011, Art. 903). Among them, there's the rule of law, objectivity, effectiveness, independence, and transparency. And although the principle of ensuring and protecting the interests of society in this federal law is not directly stipulated, the legislator has fixed a number of mechanisms ensuring its implementation. In the next section, the examples are presented.

\section{Principle of Transparency in Activity of Control Bodies}

Let us begin with securing the principle of transparency in the activities of control and accounting bodies of the constituent entities of the Russian Federation (Hereinafter referred to as $\mathrm{CAB}$ of the subjects of the Russian Federation) which involves two components:

1) informing the public about the main activities and results of the control and accounting body,

2) exercising control by civil society institutions over the activities of the $\mathrm{CAB}$ (Control and Accounts Body) of the subject of the Russian Federation, the use of feedback mechanisms from the facility to the subject of management.

First, the public is informed of the results of its activities in the following ways:

- by providing the final (annual) and current reports of the state and municipal financial control authorities to the bodies that formed them and other authorities;

- by publishing the reports on the results of inspections, as well as information on taking measures to eliminate the identified violations (except for information containing confidential information, access to which is limited by the current legislation) in mass media;

- by legislative consolidation of the procedure for publicizing the results of control.

In the legislation of the constituent entities of the Russian Federation, guarantees are provided for the implementation of the principle of transparency. Thus, in Art. 22 of the Krasnodar Krai Law on the Control and Accounts Chamber of the Krasnodar 
Territory it is established that the Control and Accounts Chamber annually in the first quarter of the year following the reporting year submits a report on its activities to the Legislative Assembly of the Krasnodar Krai. The report of the Control and Accounts Chamber is published in the media or published on the official site of the Control and Accounts Chamber on the Internet only after it has been considered by the legislative assembly of the territory.

The Control and Accounts Chamber, in order to provide access to information about its activities, places on its official website the Internet and publishes in its official publications or other mass media information about the monitoring and expert-analytical activities carried out, the violations detected during their conduct, submitted applications and prescriptions, as well as decisions and measures taken on them.

Publication of information on the activities of the Control and Accounts Chamber in the mass media and posting on the Internet is carried out in accordance with the legislation of the Russian Federation, the legislation of the Krasnodar Territory and the regulations of the Control and Accounts Chamber.

Similar provisions are contained in (Act On the Control and Accounts Chamber of Moscow Region, Part 3.1-6 of Art. 23). This article also establishes that the Control and Accounts Chamber publishes an Information Compendium of the Control and Accounts Chamber of Moscow Region, which is its official information publication. The information collection of the Control and Accounts Chamber of the Moscow Region is issued quarterly in an electronic form and posted on the official website of the Control and Accounts Chamber on the Internet.

The annual report on the activities of the Control and Accounts Chamber is subject to official publication by the Control and Accounts Chamber in the newspaper "Daily News. Moscow Region" and the Information Collection of the Control and Accounting Chamber of the Moscow Region (Antroptseva et al.: 2016).

Second, exercising control by civil society institutions over the activities of the $\mathrm{CAB}$ (Control and Accounts Body) of the subject of the Russian Federation, the use of feedback mechanisms.

One should note that there is a well-organized system of feedback and interaction with citizens. Thus, on official sites of control and accounting bodies the schedule of work of the body, contact information is available, as well as an opportunity to send an appeal for consideration on-line (for example see: official site of the Control and Accounts Chamber of the Bryansk Region. www.kspbo.ru/ksp-bo). 
Public Interests Provision in the Activities of Control and Accounts Bodies...

The presence of these options indicates the involvement of the control and accounting body in the process of introducing information technologies, as well as its development towards more transparent and open interaction with citizens and other authorities.

CABs of the subjects of the federation post information on the results of consideration of applications of citizens on their official websites. For example, in 2016, the Control and Accounts Chamber of the Khabarovsk Territory received 16 appeals from citizens and representatives of organizations. The considered appeals dealt with issues of violation of budget legislation, provision of high-quality medical assistance, misuse of funds of the regional budget, verification of accounts receivable of consumers of water and wastewater services. The citizens appealed to the Control and Accounts Chamber with complaints about the actions of officials.

At the request, containing an appeal to conduct an audit to assess the legality of granting financial benefits and preferences to officials of local government, clarifications and materials were sent to the Khabarovsk Krai Prosecutor's Office to take measures of prosecutorial response. On the basis of one appeal in 2016, the Control and Accounts Chamber of the Khabarovsk Territory conducted a control measure for the legality, effectiveness (efficiency and economy) of using the funds of the regional budget allocated for the construction of the "Social and cultural center in the village of Data of the Vanino district". The report on the results of the control measure was sent to the regional prosecutor's office and the Ministry of Construction of the Khabarovsk Territory. The review of applications of citizens who entered the Control and Accounts Chamber of the Khabarovsk Territory in 2016 was published at the official website of the given CAB (Control and Accounts Chamber of the Khabarovsk Territory).

The website of the Control and Accounts Chamber of the Republic of Crimea shows only general statistics for 2015 and 2016. So, in 2016 the Control and Accounts Chamber of the Republic of Crimea received 30 appeals, one of which is collective.

Next, an analysis is made of the appeals received during the reporting period, from which it follows that the largest number of letters contain requests for verification activities in relation to state budgetary institutions, state unitary enterprises, as well as information on irrational, inefficient use of budget funds by officials of enterprises, institutions and organizations. However, the results of consideration of the received applications on the site are not given (Accounts Chamber of the Republic of Crimea). It should be noted that not all CAB sites of RF subjects contain information on the number of applications received and the results of their consideration, either the section i-reception or "citizens' appeals". The analysis of 
Elena Kireeva

information on citizens' appeals presented on the official websites of CAB subjects of the Russian Federation is presented in the form of a comparative table $1^{2}$.

Table 1 Citizens' Appeals in the Russian Federation

\begin{tabular}{|c|c|c|c|c|}
\hline & $\begin{array}{l}\text { Name of the CAB of the } \\
\text { subject of the RF }\end{array}$ & Official website & Number of appeals in 2015 & $\begin{array}{l}\text { Number of appeals } \\
\text { in } 2016\end{array}$ \\
\hline 1 & $\begin{array}{l}\text { Control and Accounts } \\
\text { Chamber of the Republic } \\
\text { of Adygea }\end{array}$ & www.kspra.ru & $\begin{array}{l}\text { The page "Information on citizens' } \\
\text { appeals" is not active }\end{array}$ & \\
\hline 2 & $\begin{array}{l}\text { Control and Accounting } \\
\text { Chamber of the Altai } \\
\text { Republic }\end{array}$ & www.ksp04.ru & $\begin{array}{c}\text { Information on citizens' appeals is not } \\
\text { available }\end{array}$ & \\
\hline 3 & $\begin{array}{c}\text { Control and Accounting } \\
\text { Chamber of the Republic of } \\
\text { Bashkortostan }\end{array}$ & www.ksp02.ru & 206,39 of which are collective & $\begin{array}{l}\text { 237, } 31 \text { of which are } \\
\text { collective }\end{array}$ \\
\hline 4 & $\begin{array}{c}\text { Control and Accounting } \\
\text { Chamber of the Republic of } \\
\text { Buryatia }\end{array}$ & www.sp03.ru & $\begin{array}{l}\text { The page "Information on citizens' } \\
\text { appeals" is not active }\end{array}$ & \\
\hline 5 & $\begin{array}{c}\text { Control and Accounting } \\
\text { Chamber of the Republic of } \\
\text { Dagestan }\end{array}$ & www.spdag.ru & $\begin{array}{l}\text { Electronic application form is } \\
\text { provided. The page "Appeals } \\
\text { statistics" is not active }\end{array}$ & $\begin{array}{l}\text { control measures } \\
\text { were taken in } 16 \\
\text { for } 24\end{array}$ \\
\hline 6 & $\begin{array}{c}\text { Control and Accounts } \\
\text { Chamber of the Republic of } \\
\text { Ingushetia }\end{array}$ & www.kspri.ru & & 5 job applications \\
\hline 7 & $\begin{array}{c}\text { Control and Accounts } \\
\text { Chamber of the Kabardino- } \\
\text { Balkarian Republic }\end{array}$ & www.kspkbr.ru & $\begin{array}{l}\text { Information on } 2 \text { appeals } \\
\text { consideration results }\end{array}$ & \\
\hline 8 & $\begin{array}{l}\text { Control Chamber of the } \\
\text { Republic of Kalmykia }\end{array}$ & www.ksprk08.ru & $\begin{array}{l}\text { Electronic application form is } \\
\text { provided. Statistics are not available }\end{array}$ & \\
\hline 9 & $\begin{array}{l}\text { Control and Accounting } \\
\text { Chamber of the Republic } \\
\text { of Karelia }\end{array}$ & www.ksp.karelia.ru & & 8 of these 1 electronic \\
\hline 10 & $\begin{array}{c}\text { Control and Accounting } \\
\text { Chamber of the Republic of } \\
\text { Tatarstan } \\
\end{array}$ & www.sprt.ru & $\begin{array}{l}\text { Electronic application form is provided } \\
\text { in the section "Electronic reception". } \\
\text { Statistics is not available }\end{array}$ & \\
\hline 11 & $\begin{array}{c}\text { Control and Accounting } \\
\text { Chamber of the Republic of } \\
\text { Sakha (Yakutia) }\end{array}$ & $\begin{array}{l}\text { www.schetnaja-palata. } \\
\text { sakha.gov.ru }\end{array}$ & $\begin{array}{l}\text { Electronic application form is provided } \\
\text { in the section "Electronic reception". } \\
\text { Statistics are not available }\end{array}$ & \\
\hline 12 & $\begin{array}{l}\text { Control and Accounting } \\
\text { Chamber of the } \\
\text { Transbaikalian Territory }\end{array}$ & www.kspzab.ru & 2 appeals & 16 appeals \\
\hline 13 & $\begin{array}{l}\text { Control and Accounting } \\
\text { Chamber of Krasnodar } \\
\text { Region }\end{array}$ & www.kspkuban.ru & The latest data is for 2012.53 appeals & \\
\hline 14 & $\begin{array}{l}\text { Control and Accounting } \\
\text { Chamber of the } \\
\text { Krasnoyarsk Territory }\end{array}$ & www.spkrk.ru & $\begin{array}{l}\text { Electronic application form is provided } \\
\text { in the section "Electronic reception". } \\
\text { Statistics are not available }\end{array}$ & \\
\hline 15 & $\begin{array}{l}\text { Control and Accounting } \\
\text { Chamber of the Stavropol } \\
\text { Territory }\end{array}$ & www.kspstav.ru & 23 appeals & 12 appeals \\
\hline 16 & $\begin{array}{c}\text { Control and Accounting } \\
\text { Chamber of the Belgorod } \\
\text { Region }\end{array}$ & www.belksp.ru & The section of appeals is missing & \\
\hline 17 & $\begin{array}{l}\text { Control and Accounting } \\
\text { Chamber of Bryansk } \\
\text { Region }\end{array}$ & www.kspbo.ru & 10 appeals & $\begin{array}{l}17 \text { of these } 1 \\
\text { electronic }\end{array}$ \\
\hline
\end{tabular}

2 Out of 85 subjects of the Russian Federation 30 subjects of the Russian Federation or $25.5 \%$ have been selected, and all types of subjects are represented: the republics of the Russian Federation, the region, the cities of federal significance, the autonomous region and the autonomous district. 
Public Interests Provision in the Activities of Control and Accounts Bodies...

\begin{tabular}{|c|c|c|c|c|}
\hline 18 & $\begin{array}{c}\text { Control and Accounting } \\
\text { Chamber of the Voronezh } \\
\text { Region }\end{array}$ & www.ksp-vrn.ru & & $\begin{array}{l}16 \text { of these } 10-\text { from } \\
\text { citizens, } 6-\text { from } \\
\text { organizations }\end{array}$ \\
\hline 19 & $\begin{array}{l}\text { Control and Accounting } \\
\text { Chamber of the Irkutsk } \\
\text { Region }\end{array}$ & www.irksp.ru & & $\begin{array}{l}137 \text { assignments and } \\
\text { appeals from citizens } \\
\text { and organizations, } \\
\text { of these } 15 \text { from } \\
\text { individuals }\end{array}$ \\
\hline 20 & $\begin{array}{c}\text { Control and Accounting } \\
\text { Chamber of the Kaliningrad } \\
\text { Region } \\
\end{array}$ & www.ksp39.ru & $\begin{array}{l}\text { Electronic application form is provided } \\
\text { in the section Public reception. } \\
\text { Statistics are not available }\end{array}$ & \\
\hline 21 & $\begin{array}{l}\text { Control and Accounts } \\
\text { Chamber of the Nizhny } \\
\text { Novgorod Region }\end{array}$ & www.ksp.r52.ru & 25 appeals, of these 10 from citizens & \\
\hline 22 & $\begin{array}{l}\text { Control and Accounts } \\
\text { Chamber of the Rostov } \\
\text { Region }\end{array}$ & www.ksp61.ru & $\begin{array}{l}\text { Online application form on corruption } \\
\text { crimes. Reception schedule of citizens }\end{array}$ & \\
\hline 23 & $\begin{array}{l}\text { Control and Accounts } \\
\text { Chamber of Tomsk Oblast }\end{array}$ & www.audit.tomsk.ru & 10 appeals, of these 1 collective & 7 appeals \\
\hline 24 & $\begin{array}{l}\text { Control and Accounting } \\
\text { Chamber of the Yaroslavl } \\
\text { Region }\end{array}$ & $\begin{array}{l}\text { www.kspalata76. } \\
\text { yarregion.ru }\end{array}$ & 19 appeals, of these 16 from citizens & 12 appeals \\
\hline 25 & $\begin{array}{l}\text { Control and Accounting } \\
\text { Chamber of Moscow }\end{array}$ & www.ksp.mos.ru & 3575 appeals and inquiries & $\begin{array}{l}3483 \text { of these } 277 \\
\text { from citizens, } 521 \\
\text { appeals from entities }\end{array}$ \\
\hline 26 & $\begin{array}{l}\text { Control and Accounts } \\
\text { Chamber of St. Petersburg }\end{array}$ & www.ksp.org.ru & $\begin{array}{l}\text { Electronic application form is provided } \\
\text { in the section Electronic reception. } \\
\text { Statistics is not available }\end{array}$ & \\
\hline 27 & $\begin{array}{l}\text { Control and accounting } \\
\text { chamber of Sevastopol }\end{array}$ & www.ksp-sev.ru & $\begin{array}{l}\text { Electronic application form is provided } \\
\text { in the section "Appeals from citizens". } \\
\text { Statistics are not available }\end{array}$ & \\
\hline 28 & $\begin{array}{l}\text { Control and Accounts } \\
\text { Chamber of the Jewish } \\
\text { Autonomous Region }\end{array}$ & www.eao.ru & $\begin{array}{l}\text { Information on the results of work with } \\
\text { citizens' appeals in the Government of } \\
\text { the Jewish Autonomous Region and } \\
\text { local bodies is provided }\end{array}$ & \\
\hline 29 & $\begin{array}{l}\text { Control and Accounting } \\
\text { Chamber of the Nenets } \\
\text { Autonomous District }\end{array}$ & www.cпнао.pф & No appeals & \\
\hline 30 & $\begin{array}{l}\text { Control and Accounting } \\
\text { Chamber of the Yamalo- } \\
\text { Nenetsk Autonomous } \\
\text { District }\end{array}$ & www.spyanao.ru & $\begin{array}{l}\text { Section on work with appeals from } \\
\text { citizens is missing }\end{array}$ & \\
\hline
\end{tabular}

Source: Own elaboration.

\section{Conclusions}

Based on the information given above one can draw the conclusions, as follows.

First, currently, the created information resources ensure publicity in the work of $\mathrm{CAB}$ of the subjects of the Russian Federation by providing information on the composition, structure, performance (publication of reports, statistical and analytical materials), contact information including schedules for citizens.

Second, the opportunity to receive feedback on existing violations of budget legislation through posting information on the procedure for filing and reviewing applications, the availability of the on-line reception section, or the placement of 
electronic circulation forms on the $\mathrm{CAB}$ websites of the constituent entities of the Russian Federation was created.

Third, on average 10-15 appeals from citizens and legal entities (with the exception of Moscow) are received annually by the $\mathrm{CAB}$ of the subject, of which about 40$60 \%$ (in different subjects the figures vary) refer to the facts of violation of budget legislation, and accordingly, cause carrying out control measures.

Fourth, the subjects of the Russian Federation keep records of incoming appeals in different ways, including requests or orders from state and local government bodies or taking into account only appeals of citizens and legal entities, therefore statistical indicators vary greatly.

Fifth, the appeals directed to the control and accounts bodies of the constituent entities of the Russian Federation can be classified into several groups. First, the subjective composition: individual and collective; physical, legal persons, public authorities and local self-government; second, the form ones: written, oral (filed during the reception of citizens), online appeals; third, content ones: violations of the current legislation, facts of ineffective use, or evaluation of the effectiveness and effectiveness of spending budget funds, explaining the current legislation, public service and employment issues.

Sixth, there is a number of problems and shortcomings in terms of ensuring the interaction of citizens and control and accounts bodies, among which one can point out that some websites do not provide the possibility of submitting on-line appeals, as well as obtaining information on the results of the examination of the latter (Republic of Buryatia, Belgorod Region, and others, at the time of writing this article the official site of the CAB of Chukotka Autonomous Okrug did not work at all). The information provided on the official websites is outdated or is not updated (Krasnodar Territory), or not related to CAB activities (Jewish Autonomous Region has posted a report on the work with the appeals of the Government of this entity, the $\mathrm{CAB}$ of Ingushetia takes into account applications for employment). There are no unified requirements for the structure and content of $\mathrm{CAB}$ websites of entities and for keeping statistical reports on incoming and considered appeals.

\section{References}

Antroptseva, I.O., Kireeva, E.Yu. et al.: Комментарий к Федеральному закону от 7 февраля 2011 г. № 6-Ф3 Об общих принципах организации и деятельности контрольносчетных органов субъектов Российской Федерации и муниципальных образований (постатейный) (Commentary to Federal Law no. 6-FZ of 7 February 2011 on General Principles of Organization and Operation of Control and Accounting Bodies of Subjects of the Russian Federation and Municipal Formations (itemized), 2016. www.consultant.ru. 
Public Interests Provision in the Activities of Control and Accounts Bodies...

Информационный бюллетень Законодательного Собрания Краснодарского края (Information Bulletin of the Legislative Assembly of Krasnodar region) no. 4 (2011).

LT: Constitution of the Republic of Lithuania of 25 October 1992.

RU: Constitution of the Russian Federation of 12 December 1993.

RU: Act 6-FZ/2011, on the general principles of organization and operation of control and accounting bodies of the subjects of the Russian Federation and municipal entities, as amended.

RU: Krasnodar Krai Law no. 2321-KZ/2011, on the Control and Accounts Chamber of the Krasnodar Territory, as amended.

RU: Act no. 135/2010-OZ, on the Control and Accounts Chamber of Moscow Region, as amended.

PL: Constitution of the Republic of Poland of 2 April 1997, as amended. 